$P N L-4597$

NUREG/CR-3166 PNL-4597

\title{
Recommended Procedures for Measuring Radon Fluxes from Disposal Sites of Residual Radioactive Materials
}

Prepared by J. A. Young, V. W. Thomas, P. O. Jackson

Pacific Northwest Laboratory Operated by

Battelle Memorial Institute

Prepared for U.S. Nuclear Regulatory Commission 


\section{NOTICE}

This report was prepared as an account of work sponsored by an agency of the United States Government. Neither the United States Government nor any agency thereof, or any of their employees, makes any warranty, expressed or implied, or assumes any legal liability of re. sponsibility for any third party's use, or the results of such use, of any information, apparatus, product or process disclosed in this report, or represents that its use by such third party would not infringe privately owned rights.

\section{Availability of Reference Materials Cited in NRC Publications}

Most documents cited in NRC publications will be available from one of the following sources:

1. The NRC Public Document Room, 1717 H Street, N.W.

Washington, DC 20555

2. The NAC/GPO Sales Program, U.S. Nuclear Regulatory Commission, Washington, DC 20555

3. The National Technical Information Service, Springfield, VA 22161

Although the listing that follows represents the majority of documents cited in NRC publications, it is not intended to be exhaustive.

Referenced documents available for inspection and copying for a fee from the NRC Public Document Room include NAC correspondence and ir.ternal NRC memoranda; NAC Office of Inspection and Enforcement bulletins, circulars, information notices, inspection and investigation notices: Licensee Event Reports; vendor reports and correspondence; Commission papers; and applicant and licensee documents and correspondence.

The following documents in the NUREG series are available for purchase from the NRC/GPO Sales Program: formal NRC staff and contractor reports, NRC-sponsored conference proceedings, and NRC booklets and brochures. Also available are Regulatory Guides, NRC regulations in the Code of Federal Regulations, and Nuclear Regulatory Commission /ssuances.

Documents available from the National Technical Information Service include NUREG series reports and technical reports prepared by other federal agencies and reports prepared by the Atomic Energy Commission, forerunner agency to the Nuclear Regulatory Commission

Documents available from public and soecial technical libraries include all open literature items. such as books, journal and periodical articles, and transactions. Federal Register notices, federal and state legislation, and congressional reports can usually be obtained from these libraries.

Documents such as theses, dissertations, foreign reports and translations, and non-NAC conference proceedings are available for purchase from the organization sponsoring the publication cited.

Single copies of NAC draft reports are available free upon written request to the Division of Technical Information and Document Control, U.S. Nuclear Regulatory Commission, Washington, DC 20555.

Copies of industry codes and standards used in a substantive manner in the NRC regulatory process are maintained at the NRC Library, 7920 Norfolk Avenue, Bethesda, Maryland, and are available there for reference use by the public. Codes and standards are usually copyrighted and may be purchased from the originating organization or, if they are American National Standards, from the American National Standards Institute, 1430 Broadway, New York, NY 10018 


\section{Recommended Procedures for Measuring Radon Fluxes from Disposal Sites of Residual Radioactive Materials}

Manuscript Completed: February 1983

Date Published: March 1983

Prepared by

J. A. Young, V. W. Thomas, P. O. Jackson

Pacific Northwest Laboratory

Richland, WA 99352

\section{Prepared for}

Division of Waste Management

Office of Nuclear Meterial Safety and Safeguards

U.S. Nuclear Regulatory Commission

Washington, D.C. 20555

NRC FIN B2216 



\section{ABSTFACT}

This report recomends instrurentation and metrods suitable for measuring radon fluxes emanating from covered disposa sites of residual radioactive materials such as urenilum mill tailings. Probiems of spatial and temporal varjations ir radon flux are discussed and the advantages and disadvantages of several instruments are examined. A year-lorg measurement program and a two month measuremen: methodology are then presented based on the inherent difficulties of measuring average radon flux over a cover using the recomended instrumeritation. 



\section{TABLE OF CONTENTS}

I. Introduction $\ldots \ldots \ldots \ldots \ldots \ldots \ldots \ldots \ldots \ldots \ldots \ldots \ldots, 1$

II. Spatial and Temporal

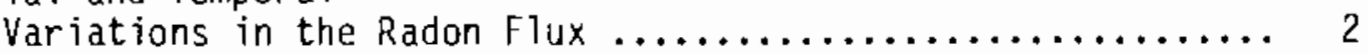

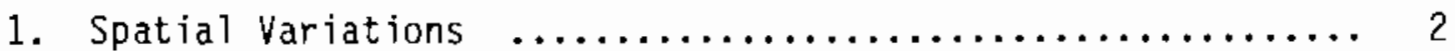

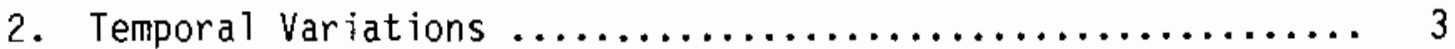

A. Introduction $\ldots \ldots \ldots \ldots \ldots \ldots \ldots \ldots \ldots \ldots \ldots \ldots \ldots \ldots, 3$

B. Moisture Content $\ldots \ldots \ldots \ldots \ldots \ldots \ldots \ldots \ldots \ldots, 3$

C. Ice $\ldots \ldots \ldots \ldots \ldots \ldots \ldots \ldots \ldots \ldots \ldots \ldots \ldots \ldots \ldots, 4$

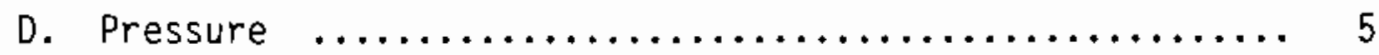

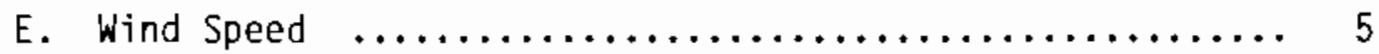

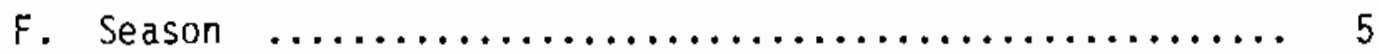

G. Diurnal Variations $\ldots \ldots \ldots \ldots \ldots \ldots \ldots \ldots \ldots \ldots \ldots, 6$

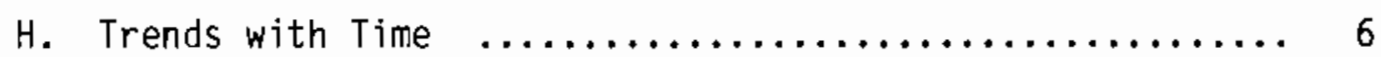

III. Radon Flux Measurement Techniques $\ldots \ldots \ldots \ldots \ldots \ldots \ldots \ldots \ldots, 7$

1. Introduction $\ldots \ldots \ldots \ldots \ldots \ldots \ldots \ldots \ldots \ldots \ldots \ldots \ldots \ldots, 7$

2. The Charcoal Canister Method $\ldots \ldots \ldots \ldots \ldots \ldots \ldots \ldots \ldots, 7$

3. The Flow Method $\ldots \ldots \ldots \ldots \ldots \ldots \ldots \ldots \ldots \ldots \ldots \ldots, 8$

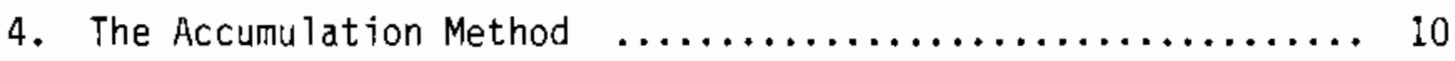

5. Track Etch ${ }^{\oplus}$ and Thermoluminescent Dosimeter (TLD) Detectors $\ldots \ldots \ldots \ldots \ldots \ldots \ldots \ldots \ldots, 11$

IV. Procedures for Conducting Radon Flux Surveys $\ldots \ldots \ldots \ldots \ldots \ldots, 12$

1. Summary of Recommended Procedures $\ldots \ldots \ldots \ldots \ldots \ldots \ldots \ldots, 12$

2. Gamma-Ray Surveys $\ldots \ldots \ldots \ldots \ldots \ldots \ldots \ldots \ldots \ldots \ldots \ldots \ldots \ldots \ldots \ldots \ldots \ldots \ldots, 13$

3. Radon Flux Sampling Grid $\ldots \ldots \ldots \ldots \ldots \ldots \ldots \ldots \ldots \ldots \ldots \ldots \ldots \ldots$

4. Time Schedule of Flux Measurements $\ldots \ldots \ldots \ldots \ldots \ldots \ldots \ldots, 14$

A. Year-Long Measurement Series $\ldots \ldots \ldots \ldots \ldots \ldots \ldots \ldots . \ldots \ldots$ 


\section{TABLE OF CONTENTS (continued)}

B. Two-Month Measurement Series................. 17

V. Calibration of Radon Flux heasuring devices $\ldots \ldots \ldots \ldots \ldots \ldots .17$

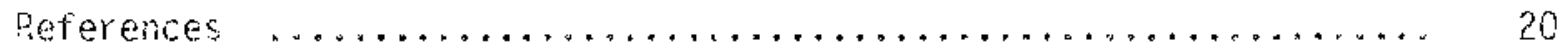


RECOMMENDED PROCEDURES FOR MEASURIAG RADON HLUXES FROM DISPOSAL STIES OF RESIOUAL RADIOACTIVE MATERIALS

J. A. Young, V. W. Thomas anc P. O. Jackson

\section{Introduction}

The U. S. Erivironmenta Protection Agency (EFA) interim environmental standards for the disposal of residual radioactive materials from inactive uranium processing sites were published in the Federai Register in January 1981 (40 OFR 192). A7though the Department of Energy (DOE) has the primary responsibility for the implementation of these EPA staidards, PL-95-604 reguires that the Nuclear Regulatory Comnssion (NRC) concur in remedial actions. One of the requirements of the interin standards is that disposal of residual radioactive materials from inactive uranium processing sites shall de conducted in a way that proudes a reasonable expectation that the average annual release of radon-22? trom the disposal sites to the atmosphere by residuai radioactive materials following disposal will not exceed $2 \mathrm{pCi} / \mathrm{m}^{2}-\mathrm{sec}$ for at least 1000 years following disposa?. However, the EPA has recently proposed that the standard be changed to require that the flux shall not exceed 20 pci/mi $-\mathrm{sec}^{2}$ for at least 200 years, and to the extent practicabie, 1000 years. It is expected that the rador flux standard will be interpreted to require that the annual average flux from a tailings pile, rather that the flix at any location on the pile, snal! not exceed the standard.

It is anticipated that the reduction of radon enisstons fron disposal sites will be accomplished by covering the tailings with a layer, or layers, of earthen material. However, it is possible that a layer of material such as asphalt will also be laid down to act as a rador barrier. The cover will decrease the emission of radon into the atmosphere because of the radioactive gecay of the radon daring its diffusion through the cover. The radon emission will also be decreased because the cover will reduce the concentration gradient and therefore tife rate of diffusion of radon from the tailings.

The rador fiux from a covered tajlings pile will come from both the tailings and the covering materia?. The radon emission standard will be considered to be satisfied for a disposal site if the radon flux is iess than we equal to the standard pius the exhalation rate of the cover

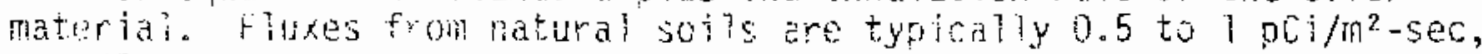
but fluxes up to several times these values are not unusual. Therefore, the rador fluxes from possible cover matericls at ean disposal site should be determiried as part of the dispos $\mathrm{p}^{2}$ ?

The fina! EfA standand corcenting radon fluxes ing to the form of either a performance standard or a design objective a perromaroes starbard would require that radon flux measurements be performet to vertiv compliance. A design objertive would requ ire only that the cover 
be designed to lower the calculated radon flux below a given value. Flux measurements would not be required to verify compliance with a design objective. However, radon flux measurements would still be useful for the experimental purpose of verifying that the design cover is functioning as planned.

This report has been preparad for NRC to recommend procedures for measuring radon fluxes from disposal sites of residual radioactive material after they have been covered to reduce the radon flux. It will recommend sampling programs, instrumentation, analytical procedures, data reporting formats, and statistical analys is of the data that should be used in the determination of radon fluxes.

II. Spatial and Temporal Variations in the Radon Flux

1. Spatial Variations

The determination of average radon fluxes from disposal sites is complicated by the fact that there may be large spatial and temporal variations in the flux from a given disposal site. The flux from a tailings pile varies with location on the pile because of variations in thickness of the pile and variations in the particle size, ${ }^{26} \mathrm{Ra}$ concentration, moisture content, and emanating power of the material added to the pile (the emanating power is the fraction of the radon atoms produced by ${ }^{226} \mathrm{Ra}$ that escapes the crystal 1attice and is free to diffuse). Measured radon fluxes have varied by more than an order of magnitude with location on tailings piles (Silker and Heasler, 1979; Ford, Bacon and Davis Utah Inc., 1981).

According to Leggett, et a1. (1978), the number of locations at which a parameter must be measured to determine its average value with a precision of $25 \%$ at the $95 \%$ confidence level is given by

$$
\text { Number }=45(\text { coefficient of variation })^{2}
$$

The coefficient of variation of the radon flux measurements made by Silker and Heasler (1979) at several locations on the Grants, New Mexico tailings pile was 0.74. Freeman (1981) found that the coefficient of variation with location was 0.84 for the Grand Junction tailings pile. The coefficients of variation of the radon flux measurements made by Ford, Bacon and Davis Utah Inc. (1981) also averaged 0.84 for several uncovered tailings piles. According to Equation (1), the number of locations at which the flux would have to be measured to determine the average within $25 \%$ at the $95 \%$ conf $i$ dence level would be 25 if the coefficient of variation were 0.74 , and 32 if it were 0.84 .

The variation of the radon flux across a covered tailings pile could be somewhat less than that across an uncovered pile because horizontal diffusion of radon in the cover material would be expected 
to lower horizontal concentration gradients. However, if the cover material were not uniform, or if cracks developed in it, the spatial variation of the flux from a covered tailings pile could be greater. The coefficient of variation of the radon fiux measurements made by Ford, Bacon and Davis Inc. (1981) averaged 0.66 for several tailings piles covered by about six inches of soil. According to Equation (1), measurements at only 20 locations would be required for this coefficient of variation. However, Leggett, et al. (1978) also recommends that measurements be made at a minimum of 30 locations. It therefore appears that in most cases flux measurements should be made at 30 locations, although in some cases measurements of more locations would be required because of higher variations in the radon flux.

\section{Temporal Variations}

\section{A. Introduction}

The radon flux from a given location at a disposal site will also show considerable variation with time as a result of changes in meteorological conditions, moisture content of the tailings, and perhaps settling of the cover material. According to Baver (1956), the meteorological factors influencing the radon flux are, in order of decreasing importance, rainfall, variations in barometric pressure, varjation of soil and atmospheric temperature, and wind speed. He estimated that together these factors are responsible for less than $10 \%$ of normal soil aereation.

\section{B. Moisture Content}

The radon flux will depend greatly upon the moisture content of the tailings and cover material. The fraction of radon atoms produced by $228 R a$ decay that escape the crystal lattice increases with moisture content. When a $226 \mathrm{Ra}$ atom decays by alpha particle emission the radon atom that is formed recoils in a direction opposite from that taken by the alpha particle. If the recoiling atom comes to rest inside a grain of the material, it is very likely to remain entrapped, but if it comes to rest in a pore it will be free to diffuse into the atmosphere. However, the pores of compacted natural materials are likely to be smaller than the recoil range of radon atoms in a gas, so a recoiling atom that enters a gas-filled pore is very likely to cross the pore and become entrapped in a neighboring grain (Tanner, 1980). The recoil range in water is about one hundred times less than that in air, so the probability that a recoiling atom will stop in a pore is greatly enhanced if the pore is water-filled. 
The rate of diffusion in water is ruch less than that in air so the rate of diffusion into the atmsophere of the radon atoms that have escaped the crystai lattice wili he lowered by increasing the moisture corteil of either the tainings or the cover material. Therefore, increased moisture content could either raise or lower the radon fiux. According to Momeni, et al. (1979), the radon flux from domestic uranium ores varies only slightly with moisture content between $10 \%$ and $80 \%$ sotijration. On the other hand, Rogers, er ai. (1979) found thai the flux from tailings decreased by a fiactor of 100 when the moisture content increased from ary to saturation. The apparent contradiction of these resi?ts is explained by tre observations of Strong and Levins (1982), who Ireasurtal the filux of radon from a column of mili toilings as a funition of moisiare content. They found that the flux increasad by a factor of 3.5 winen the moisture content increased from 0.2 to $5.7 \%$ by $y$ sht. 2 th then increased only slow? $y$ with increas ng motsture content unt? saturation was reaches, at which time deteded sharply. They estimated that the radon flux from ar infinitely thick

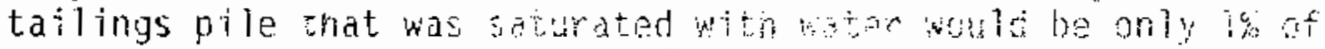
that from a pile containirit $5.7 \%$ water.

According to homent, et $21 .(197)$, a isture content of $0.2 \%$ is typical for dry tatiogs in a southestern olinate. Increasing the moisture ontent ot thse to ilings would be an. pected to increase the flux. However; if the tallings were covered by a iayer of earthen material, increasing the moisture content of the cover material wojd decrease the rate of ditfusion of radon through the cover and brer the fiox. A heang rainfall might not immediately ircrease the no isture content cr the tailings, but it wolld incresse the molsture content of the cover material, thereby greatly decreasing the racon flix. Therefore, flux measurement.s male following a reoyy roin should not be used to determine dverage trises.

\section{Ice}

Several investigators have 2500 obsurier that a cover of ice will sharply reduce the radon flux rom orustai surfaces. Pearson and lones (1965, 1966) obscruad that the flux increasod by a factor of two or more wher a witer tha resulted in the disappearance of an ice cover. Countess (1977) otserved thet: a 1000-foid reduction in the flux fron a tailings pile persisted for several weeks followirg the formition of an jie cover on the pile. Therefore, the average flu frim a tiling pile

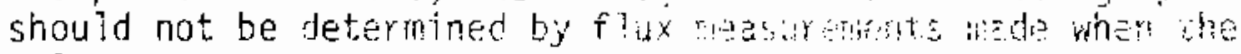
pile is covered with ict. 


\section{Pressure}

Decreasing atmospheric pressure draws interstitial gas toward the surface, thereby increasing the radon flux; and increasing pressure pumps it away from the surface, thereby decreasing the flux. According to Clements and Wilkening (1974) atmospheric pressure changes of $i \%$ or less cause 50 to $100 \%$ changes in the exhalation rate of soil, with the actual change depending upon the rate of change of the pressure and the duration of the change. A frequently quoted figure is that a $1 \%$ atmospheric pressure change will cause approximately a $60 \%$ change in the radon flux (Colle, et al., 1981). Bogoslovskaya, et al. (1932) found that the flux from uranium ore would vary by an order of magnitude with atmospheric pressure, even if the ore were buried five meters below the surface.

\section{E. Wind Speed}

It is not known for certain how significant a role wind speed plays in determining radon fluxes. The uncertainty is partly due to the fact that radon flux measuring devices interrupt the flow of air across the material whose flux is being measured. Therefore, it is not possible to be certain that the flux from the material is the same as it would be if the flux measuring device were not there. Pearson and Jones (1966) found no obvious correlation between wind speed and the radon flux from grass-covered soit in Illinois at the very low wind speeds that normally occurred near the scil surface. However, at abnormally high wind velocities the flux increased linearly with velocity. Kraner, et al. (1964) measured higher fluxes on unstable days with higher wind speeds. They postulated that the increase occurred because the microoscillations in barometric pressure that are associated with wind gave rise to turbulent pumping that resulted in the exchange of a layer of soil gas with radon free air from above the surface. Israel and Horbert (1970) measured about a four-foid increase in the radon flux from soil when the wind speed increased from 1 to 13 msec $^{-1}$. However, their measurements were performed on moist soil, and they concluded that the increase in the flux was due

to a decrease in the soil moisture content at higher wind speeds. Because of the possibility that radon fluxes increase with increasing wind speed, fluxes should not be measured during high winds.

\section{F. Season}

The radon flux can be expected to show seasonal variations at locations that show seasonal variations in factors such as soil moisture or ice cover. Megumi and Mamuro (1973), however, found little seasonal variation at 0saka. Bakulin (1969) found 
that the seasonal variations were not more than $10 \%$, with maximums occurring in summer. Because of the possibility of systematic seasonal variations, the radon flux should be measured at uniform intervals throughout the course of a year in order to obtain a reliable value for the average flux.

\section{G. Diurnal Variations}

The radon flux may be expected to show diurnal variations because of (1) the diurnal pressure wave, which produces a minimum in the pressure in the afternoon; (2) turbulent mixing in the atmosphere which leads to an increase in the flux during the day; ard (3) changes in convective flow due to temperature differences in the soil between day and night. Pearson and Jones (1966) found that the flux from soil in Illinois was highest near sunrise and in the mid-afternoon when the atmosphere was most turbulent near the soil surface. The maximum (hourly) radon fluxes during the day were around seven times the fluxes measured during the stable nighttime. Duwe (1976) concluded from a study of the measurements by seven investigators that. the most likely pattern of radon flux is a broad nignttime minimum, an increase during the morning to an average value of about 2.5 times the minimum, a decrease during the early afternoon, and a second increase during the late afternoon to an average value of about 1.5 times the minimum. Duwe also concluded from model calculations that soils with low permeability would show lower diurnal flux variations. Because of the likelihood of diurnal variations in the radon flux, radon flux measurements should, if possible, be made over time periods that are multiples of 24 hours.

H. Trends with Time

Radon fluxes from stabilized tailings piles could show systematic trends with time because of factors such as (1) changes in the moisture content of the tailings and cover materiai, (2) development of fissures in the cover, (3) erosion, (4) the action of burrowing animals, and (5) the growth of vegetation. Changes in the moisture content would be particularly likely to cause significant trends. If the cover material were sprinkled with water during its addition, the radon flux might be expected to increase rapidly with time at first, and then change more slowly after that as equilibrium moisture content was approached. This author is not aware of any available data that could be used to determine the time period required for moisture content and radon fluxes to approach equilibrium levels. The time required would depend upon the climate and the nature of the cover material. Therefore, radon flux measurements at a few locations on at least two tailings piles should be made at least once a month for about a year to determine the time that should be allowed 
for the fluxes to approach equilibrium values before extensive measurements to determine the average fiux are injtiated. After the fluxes have approached equilibrium values on these two piles, the flux measurements should be continued on a once a year sampling schedule for as long as possible to determine the nature of any long-term trends.

\section{Radon Flux Measurement Techniques}

1. Introduction

Several investigators have used various types of accumulators or charcoal canisters to measure radon fluxes. However, at the present time there exists no facility that can be used to accurately calibrate these flux measuring devices under varying meteorological conditions. The flux is generally calculated by dividing the total quantity of radon collected in the device by the area covered by the device and by the sampling time. Therefore, it is not really possible at the present time to compare the accuracies with which the various devices measure the radon flux.

\section{The Charcoal Canister Method}

Several investigators have employed various types of passive charcoal canisters to measure the radon flux. The canister containing charcoal is placed directly in contact with the surface. The charcoal adsorbs the emanating radon, and after a period of time ranging from a few hours to a few days the charcoal is removed and the average flux determined from the quantity of radon adsorbed on the charcoal. The radon is usually measured by sealing the charcoal in an air tight container, allowing the charcoal to sit for a few hours to allow the short-lived radon daughters to come to equilibrium with the radon, and counting the gamma-rays emitted by the shortlived radon daughter, ${ }^{214} \mathrm{Bi}$, using either a $\left.\mathrm{NaI}(\mathrm{T}]\right)$ or a germanium diode gamma-ray spectrometer. However, the radon can also be desorbed from the the charcoal and counted in a ZnS scintillation detector cell. The charcoal canister method has the advantage that many measurements can be made inexpensively because of the low cost of the canisters and the ease with which they can be deployed and recovered.

Countess (1977) has used a modified U.S. Army MII gas mask charcoal canister to measure radon fluxes. This canister covers an area of $87 \mathrm{~cm}^{2}$ and contains $148 \mathrm{~g}$ of activated charcoal. Countess (1977) reports that a lower limit of detection of $0.03 \mathrm{pCi} / \mathrm{m}^{2}-\mathrm{sec}$ can be obtained for a four-day exposure using this canister. This detection limit should be more than adequate for determining whether the flux is greater than $2 \mathrm{pCi} / \mathrm{m}^{2}-\mathrm{sec}$. Mine Safety Appliance Co. manufactures an activated charcoal cartridge type GMA No. 459315 that is suitable for measuring radon fluxes. It will cover an area 
of $41 \mathrm{~cm}^{2}$ and contains $36 \mathrm{~g}$ of charcoal (Countess, 1977). It is also quite easy to construct charcoal canisters using PVC pipe or similar material.

MacBeth, et al. (1978) reported that the precision and accuracy of the charcoal canister method is $\pm 15 \%$. This figure may be optimistic, however, because a two-laboratory comparison study performed to determine whether the actual analys is of the charcoal canister is a major contributor to variations in measured fluxes found that the average difference in the measurements between the two laboratories was $16 \%$ (Horton, 1979). However, with careful counter calibration it should be possible to measure the radon with a considerably better precision than this.

Charcoal canisters have the drawback that they can only be used to measure the flux over a very limited area for a limited period of time. Therefore, they should be used to measure the flux at several locations and at several times at each location to determine the average radon flux.

Magumi and Mamuro (1972) increased the measurement area to $2,450 \mathrm{~cm}^{2}$ by spreading the charcoal over a netting laid on the ground. The charcoal was isolated from the atmosphere by covering it with PVC film. kisieleski, et al. (1980) increased the area measured by attaching an army gas mask canister to the center of a collector iid covering an area of $2,300 \mathrm{~cm}^{2}$. However, the diffusion of the radon under the collector lid to the charcoal canister may be too slow to prevent the radon concentration under the lid from rising to the level at which it lowers the net radon flux from the emanating surface, so this method could give results that are too low. Therefore, it should not be used to measure radon fluxes until it can be proved to provide accurate measurements. Any time the charcoal canister method is used, care should be taken to minimize the distance between the charcoal and the enlanating surface to prevent the radon coricentration from building up above the emanating surface.

\section{The Flow Method}

Several investigators have measured the average radon flux over a relatively large area by circulating the air under a collector through a charcoal bed. Pacific Northwest Laboratory (PNL) developed a recirculating, pressure balanced, flow-through radon flux measuring system that uses a $76 \times 122 \times 5 \mathrm{~cm}\left(9300 \mathrm{~cm}^{2}\right.$ area) aluminum tent to cover the area to be measured (Thomas, et al., 1982; Freeman, 1981). A diaphragm vacuum pump draws air through a drierite column to remove water vapor, through a filter to remove particulates, and then through an activated carbon trap to remove radon. The carbon trap consists of a $4.8 \mathrm{~cm}$ diameter convoluted tube that is filled with $400 \mathrm{~g}$ of Pittsburgh Carbon Company 8-12. mesh activated carbon. This trap has 
been shown to absorb $99.9 \%$ of the radon in air that is circulating through the trap at a rate of 2 liters per minute at a temperature of $44^{\circ} \mathrm{C}$ (Hartley, et al., 1981). This sytem is sealed to tailings by pushing the lip of the tent into the tailings. It is sealed to asphalt by means of caulking compound. After about four hours of sampling, the charcoal is transferred to a petri dish and counted after a few hours delay for ${ }^{2.4} \mathrm{Bi}$ using either a $\mathrm{NaI}(\mathrm{Tl})$ or an intrinsic germanium gamma-ray spectrometer to obtain the radon concentration.

The coefficient of variation of the radon fiux across the area covered by the PNL flux measuring system is expected to be much less than the coefficient of variation between the fluxes at widely separated locations on the tailings pile. Freeman (1981) found that the coefficient of variation of the fluxes measured at different locations on the Grand junction tailings pile using the PNL system was 0.84 . This is much larger than the coefficient of variation of 0.29 that Silker and Heasler (1981) measured between four locations within an area of $200 \mathrm{~cm}^{2}$ using a $41 \mathrm{~cm}^{2}$ area charcoal canister. Countess (1977) found an even smaller coefficient of variation between multiple measurements of radon flux over a one to two square meter area on several test surfaces. He found that the coefficient of variation ranged from 0.06 for an outdoor location in the phosphate region of Florida to 0.15 for measurements on soil in New Jersey. The variation in the flux across a covered tailings pile will be dependent upon the degree of heterogeneity of the tailings and cover material. However, if it is assumed that the coefficient of variation of the flux (as measured by a charcoal canister) across the PNL system will be 0.29 , and the coefficient of variation in the flux (as measured by the PNL system) across the entire tailings pile will be 0.84 , then it can be calculated that using a charcoal canister rather than the PNL system will only increase the coefficient of variation of the measured fluxes from 0.84 to $\left(0.84^{2}+0.29^{2}\right)^{\frac{1}{2}}=0.89$. According to Equation (1), this would only increase from 32 to 36 the number of locations at which it was necessary to measure the flux in order to determine the average flux with a $25 \%$ accuracy at the $95 \%$ conf $i$ dence level. It therefore appears that the average flux over a large area could be determined just as accurately with a charcoal canister as with the PNL system, although a few more measurements might be required. It should be remembered also that a charcoai canister can be used to measure the radon flux over a longer time period than can the flow system, so a single measurement using a charcoal canister would probably provide a better estimate of the temporal average than would a single measurement using a flow system. In summary, comparisons between a charcoal canister system and a flow systefl indicate that charcoal canisters are more effective in terms of cost and effort for measuring the average radon flux across a large area such as a reclaimed disposal site. However, the accuracies of the two techniques must still be compared using a calibration facility before a choice can be made between them. 


\section{The Accumulation Method}

The accumulation method involves the measurement of the radon that accumulates in an open-faced container that is inverted and sealed to the emanating surface. The accumulator is generally sealed to a soil surface using wet bentonite or by imbedding the rim of the accumulator several centimeters into the soil. The accumulator is sealed to rigid surfaces such as building materials using epoxy resins or other caulking agents. Accumulators of many sizes and shapes have been used, with large barrel accumulators being popular.

The radon flux is determined by measuring the initial rate of change in the radon concentrations in samples of air that are withdrawn periodically from the accumulator through a sampling port. The air in the accumulator is generally mixed with a small fan to insure that representative samples are obtained. The flux is calculated using the equation

$$
E=\frac{V}{A}\left(\frac{\Delta n}{\Delta t}+\lambda \bar{n}\right)
$$

$$
\text { where } \begin{aligned}
E & \left.=\text { radon flux (atoms } / \mathrm{cm}^{2}-\mathrm{sec}\right) \\
V & =\text { volume of accumulator }\left(\mathrm{cm}^{3}\right) \\
A & =\text { surface area of accumulator }\left(\mathrm{cm}^{2}\right) \\
\mathrm{n} & =\text { radon concentration }\left(\text { atoms } / \mathrm{cm}^{3}\right) \\
\mathrm{t} & =\text { time (sec) } \\
\lambda & =\text { radon decay constant }\left(\mathrm{sec}^{-1}\right)
\end{aligned}
$$

The rate of change in the radon concentration in the accumulator can be used to calculate the radon flux only until such time as the concentration reaches a level that is a significant fraction of the concentration in the emanating material. At that time back diffusion into the emanating material will decrease the concentration gradient in the emanating material and thereby lower the net flux into the accumulator. Wilkening, et al. (1972) recommends that the concentration in the accumulator be kept below 10\% of the soil gas concentration at a depth of $13 \mathrm{~cm}$. For most soils this concentration is reached in a matter of hours.

Errors may arise in the measurement of radon fluxes using accumulators because of errors in the measurement of the quantity of radon in the accumulator, and because the accumulator (1) changes the flux by disturbing the soil, (2) changes the soil temperature, which may change the thermal stability or the amount of radon adsorbed onto soil grains, (3) reduces the flux because of increased radon concentrations inside the accumulator and (4) changes the temperature, wind velocity, and turbulence above the soil surface (Duwe, 1976). However, the same difficulties are faced by the charcoal canister and flow methods. 
Wilkening (1977) reported that typical error limits for the accumulation method are 6 to $10 \%$. Bernhardt, et a 1. (1975) performed the most extensive evaluation and verification of the accumulation method. They found that although the counting errors were generally less than $5 \%$ for each radon sample, the precision for replicate flux measurements was typically $20 \%$ for fluxes of $100 \mathrm{pCi} / \mathrm{m}^{2}-\mathrm{sec}$ and 50 to $100 \%$ for fluxes of less than $10 \mathrm{pCi} / \mathrm{m}^{2}-\mathrm{sec}$.

The accumulator has the advantage that it can be used to measure the radon flux over a larger area than is generally measured using a charcoal canister. However, sampling time is limited because of the build-up of radon in the accumulator. The accumulator is a much more complicated and expensive device than a charcoal canister, and the measurement of radon is more complicated using the accumulator. It also appears that the precision of accumulator measurements at low radon fluxes is not very good. These factors would seem to indicate that the accumulator method would be a less satisfactory method for conducting radon flux surveys than is the charcoal canister method. However, the accumulator method could still be the method of choice if it could be shown to provide more accurate flux measurements than other techniques.

\section{Track Etch and Thermoluminescent Dosimeter (TI.D) Detectors}

Radon fluxes show large temporal variations, so average annual fluxes should be determined from several measurements during the course of a year if a measurement technique is used that is not capable of making a measurement over a period of longer than a few days. Therefore, it might seem more practical to measure the radon flux using a Track Etch or TLD detector which was buried beneath the soil surface, or attached to the surface of a material such as asphalt or concrete, and left in place for a year or more. Extensive measurements of soil gas concentrations have been made using these devices by many investigators, especially during the expioration for uranium deposits. However, the Track Etch and TLD detectors measure the radon concentration rather than the flux. Therefore, the radon concentrations would have to be measured at several depths and the effective diffusion coefficient determined before fluxes could be calculated from these concentration measurements. Alternatively, it might be possible to derive approximate empirical factors relating singiedepth radon concentrations to radon fluxes from simultaneous measurements of concentration and flux for various materials. Wilkening, et al. (1972) found that there was a good correlation between radon fiux and soil gas concentration near Socorro, New Mexico. However, the derived factors might be expected to be different for different materials, and might be expected to change with meteorological conditions and soil moisture. Therefore, it appears that the measurement of radon fluxes using Track Etch or TLD detectors would not be practical until extensive simultaneous measurements of concentrations and fluxes had been made to derive empirical factors relating concentrations to fluxes for various materials and conditions. 
IV. Procedures for Conducting Radon Flux Surveys

1. Summary of Recommended Procedures

A gamma-ray survey should be performed using a detector system such as a micro-R-meter to measure the gamma-ray exposure rates at an elevation of 80 to $140 \mathrm{~cm}$ at the grid points of 350 by $350 \mathrm{~cm}$ grid. If an increase in the exposure rate is detected at any location, a search around that location should be made at the surface for elevated contact readings. Radon fluxes should be measured at locations showing exposure rates greater than three standard deviations above the average for the tailings pile. Flux measurements should also be made at enough locations on a rectangular grid to bring the total number of measurements up to the number required by Equation (1) or to 30, whichever is greater.

Each flux measurement should be made over as long a period of time as is practical, preferably two or three days. The measurements should not be made after a heavy rain, when there is an ice cover, or during high winds. If the cover material has been spririkled with water during application, then flux measurements should not be begun until the covered tailings pile has dried out enough so that the radon fluxes have stopped increasing rapidly with time. Repeated measurements at a few locations on at least two of the first piles measured should be used to estimate how long a time should be waited. Ideally, the flux measurements should be made every other month over the course of at least one year. However, if the flux measurements are being made to determine whether the flux exceeds a performance standard, it may be necessary to complete the measurements with in a shorter period of time, so that a decision can be made as to whether further remedial action is required. In that case, flux measurements should be made once a week for two months at each location.

If the measurements are being made to determine whether the average fiux exceeds a performance standard, they should be discontinued whenever it becomes possible to be reasonably certain whether or not the average flux will exceed the standard. The measurements should be discontinued if at any time it is calculated that there is either a less than $5 \%$ probability that the average net flux will be greater than the existing flux standard, or a greater than $95 \%$ probability that the average net flux will exceed the stardard (net flux equals total flux minus the fiux from the cover material). After the measurements have been completed, the average and the coefficient of variation of the measured fluxes should be used to calculate the probability that the true average flux exceeds the standard.

On the other hand, if the flux measurements are being made to determine whether the cover is performing as designed, fluxes from at least a few tailings piles should be measured every other month for at least one year, because the fluxes could change systematically 
with time as a result of factors such as changes in soil moisture, erosion, settling of the cover material, growth of vegetation, and the action of burrowing animals. After the first year the measurements should be made once a year until it is certain that there are no significant long-term trends in the radon fluxes.

\section{Gamma-Ray Surveys}

Considerably elevated radon fluxes could occur at isolated locations on a covered tailings pile because of (1) fissures in the material used to stabilize the tailings pile, (2) elevated exhalation rates from the underlying tailings material, or (3) variations in the thickness of the stabilizing material. Elevated gamma-ray exposure rates could occur at these locations because of the emission of gamma-rays from radon daughters that would deposit on the cover material. It is quite likely that at least some of these "hot spots" would be missed during a radon flux survey consisting of measurements at 30 or so locations. Therefore, it would be desirable to determine the locations of these hot spots, and to make flux measurements at these locations.

For the above reasons, gamma-ray surveys should be conducted before radon flux measurements are made. The measurements should be made using micro-R-meters at an elevation of about 80 to $140 \mathrm{~cm}$ at the grid points of about a $3.5 \times 3.5 \mathrm{~m}$ grid (Young, et al, 1982). This is a considerably denser grid than is likely to be used for the radon flux measurements. If an increase in the gamma-ray exposure rate is detected at any location, a careful search should be made at the surface around that location for elevated contact exposure rates. The average exposure rate and the coefficient of variation of the exposure rates should then be calculated from the measurements at the grid points. Radon flux measurements should be made at locations showing exposure rates greater than three standard deviations above the average.

It may be that the gamma-ray surveys will detect no significant hot spots. If this is found to be the case for the first few tailings piles measured, then the gamma-ray surveys may be discontinued for subsequent piles.

\section{Radon Flux Sampling Grid}

According to Leggett, et a1. (1978), a parameter should be measured at 30 locations, or at a number of locations equal to 45 times the square of the coefficient of variation of the measurements between the sampling locations, whichever is greater. Therefore, in addition to the flux measurements made at locations of elevated ganmaray exposure rates, measurements should be made at enough grid points on a rectangular grid to bring the total number of measurements up to at least 30. The coefficient of variation of the measurements 
should then be calculated to determine from Equation (1) whether additional measurements should be made. If additional measurements are required, they should be made at locations where the original measurements have indicated that elevated radon fluxes might be present. It may turn out to be cost-effective to make more than 30 flux measurements initially to insure that it does not turn out to be necessary to go back later to make additional measurements.

\section{Time Schedule of Flux Measurements}

A. Year-Long Measurement Series

The radon flux at any location will fluctuate with time as a result of meteorological conditions and the moisture content of the emanating material. Since the fluctuations could have a seasona? component, radon fluxes should be measured every other month throughout at least a year to obtain the annual average. If the measurements are being conducted to determine whether the cover is performing as designed, then measurements should be made once a year after the first year or so until it appears certain that the flux is not changing significantly with time.

Each flux measurement should be made over as long a time period as is practical for the measurement techniques being used. If charcoal canisters are used, each measurement should be made over a period of at least one, and preferably two or three days because of the possibility of diurnal and other shortterm variations. It is not practical to sample over much longer time periods than this because radon has only a 3.8 day halflife, so the radon originally collected would mostly decay away before measurement if longer sampling periods were used. Also, the saturation of the charcoal by moisture and radon during longer sampling periods might lower the adsorption efficiency of the charcoal. The adsorption efficiency of the charcoa? canister system used should be determined as a function of sampling time by making side-by-side measurenents on homogene.ous tailings material whose moisture content and radon flux is higher than would be expected for the actual covered tailings piles that are to be measured. The measured radon fluxes for given time periods should then be compared with fluxes measured simultaneously over shorter time periods to determine how long a time it takes for the collection efficiency to begin to decrease. The measurement periods for tajlings piles should be kept short compared to this time.

Radon fluxes will be measured during only a small fraction of the total time even with an ambitious measurement program, so the measurements should not be made at times when it is expected that the fluxes will depart considerably from average values. Therefore, measurements should not be made following a 
heavy rain, when there is ice cover, or during high winds. It is also likely that flux measurements should not be made for a period of time following the completion of the stabilization of the tailings pile. It is probable that the cover material will be sprinkled with water following its placement on the tailings pile so that it can be packed down more readily. If this is done, the radon flux should remain below normal until the cover and tailings material dry out enough to approach equilibrium moisture conditions. Therefore, flux measurements should be made at intervals at a given location on the tailings pile to determine when fTuxes appear to stop changing systematically with time. At that time extensive measurements to determine the average flux at a given location from the covered pile may be begun. After measurements have been made on a couple of piles it may be possible to estimate the time it takes fluxes to approach representative values, so that flux measurements may be begun following this delay period on subsequent piles. However, the time required for the cover material to approach equilibrium moisture content could vary greatly with the nature of the cover material and climatic conditions.

The number of ineasurements that would be required to determine the average flux at a given location with a precision of $25 \%$ at the $95 \%$ confidence level is given by Equation (1). There have been some repeated measurements at given locations on tailings piles over extended periods of time. On the average, the measurements of Silker and Heasler (1979), Marple and Ciements (1977), and Clements, et a1. (1978) show a coefficient of variation with time of 0.4 . According to Equation (1), six measurements would be required if the measurements showed this coefficient of variation. The variation would be expected to be different at different locations, so the total number of measurements that would be required at any location would have to be determined from the coefficient of variation of the first few measurements at that location.

It may be that the radon fluxes from a given tajlings pile will either be so low that it will be clear after a few measurements that the net flux will be less than the radon flux standard, or so high that it will be clear that the average will be greater than the standard. Therefore, if the flux measurements are being conducted to determine whether the average flux exceeds a performance standard, the average and coefficient of variation of the flux should be calculated at each sampling location after the second (and each subsequent) measurement, and then be used to calculate the average and the coefficient of variation of the flux for the total pile. If it is calculated that there is either a less than $5 \%$ or a greater than $95 \%$ probability that the average flux will exceed the standard, the flux measurements should be discontinued. 
After the flux measurements have been completed, the average and coefficient of variation of the measured fluxes should be calculated to determine the probability that the true average flux exceeds the standard. If the average flux exceeds the standard, and the decision is made to add additional cover material to locations showing fluxes greater than the standard, then additional flux measurements should be made at these loca. tions following the addition of the cover material. These mea* surements should be continued until the probability that the average flux from the pile will exceed the standard is calculated to be less than $5 \%$ or greater than $95 \%$, or until the total number of measurements required by Equation (1) is completed.

It is possible that the measurements over an extended period of time will indicate that there is a continued change in the flux with time. In that case, if an extrapolation of the data indicates that net flux could change from less than to greater than the standard (or vice versa) in the future, periodic measurements should be continued, if possible, until it is possible to be reasonably certain whether the final average net flux will be greater than the standard.

The average flux calculated in the above manner will probably be somewhat higher than the true average because sampling locations have been selected where elevated fluxes are expected. The coefficient of variation of the measurements might also be expected to be greater because of this selection of sampling locations, so the number of required sampling locations calculated from Equation (1) would be expected to be greater than would be the case if measurements were made only at grid points. However, there are significant experimental errors in the measurements, and the temporal variations of the radon flux will limit the accuracy of the calculated average fluxes. Therefore, the bias in the calculated average flux caused by the selection of sampling locations should be useful in decreasing the probability that the true average flux will be greater than the standard even though the measured average flux is less than the standard.

The possibility does exist, however, that tailings piles will have a large enough number of small areas of high radon flux (hot spots) to cause the average flux, calculated in the above manner, to exceed the true average flux by an unacceptable amount. Model calculations by Mayer and Zimmerman (1981) indicate that a $1.5 \mathrm{~cm}$ diameter hole that extends completely through a $100 \mathrm{~cm}$ thick cover will increase the average flux over a 150 $\mathrm{cm}^{2}$ area by a factor of about 30 . Therefore, if a large number of hot spots are detected, the areas of these hot spots should be estimated. Each flux measurement, including the measurements at the grid points, should then be weighted according to the area it represents when the average flux is calculated. 


\section{B. Two-Month Measurement Series}

It is possible that it will be decided that the requirement of a year-long flux measurement series would produce an unacceptable delay in the verification of compliance with a performance standard. In that case, the flux measurements should be made once a week for two months, even though this shortened measurement schedule would probably result in a decrease in the accuracy of the determination of the average flux. The flux measurements should not be begun until the radon flux has approached equilibrium values. Repeated measurements at a few locations on at least two piles should be used to estimate how long to wait. If the measured fluxes change systematically with time, it may be necessary to continue the measurements, perhaps with lower frequency, until it can be predicted with reasonable certainty whether the average flux will be greater than the standard.

\section{Calibration of Radon Flux Measuring Devices}

At the present time there exists no standard calibration facility that can be used to calibrate radon flux measuring devices. Such a facility is needed to determine whether these devices are providing accurate measurements of radon fluxes. The following paragraphs will describe the characterjstics of a facility that could be constructed and used for calibrating radon flux measuring devices. It is based upon a design proposed by Kearney and Kretz (1981).

The flux calibration facility should be constructed in an air-tight chamber having dimensions of at least $2 \times 2 \times 2$ meters. A horizonta1, perforated metal plate should be attached to the inside of the chamber about $30 \mathrm{~cm}$ above the bottom of the chamber. The plate should extend completery across the chamber. A sheet of porous fabric should be laid on the plate and then covered by a layer of sand or other earthen material having low ${ }^{226} \mathrm{Ra}$ content. A standard NBS ${ }^{26} \mathrm{Ra}$ source should be dissolved in an acid solution and placed in a bubbTer in the air space underneath the layer of sand. A pump should be used to recirculate the air undernezith the sand bed through the bubbler to transfer the radon produced by ${ }^{22 \mathrm{Ra}}$ decay into the air beneath the sand bed ${ }_{26}$ The air should be bubbled through water before being bubbled through the ${ }^{226} \mathrm{Ra}$ solution to prevent the ${ }^{26} \mathrm{Ra}$ solution from evaporating away. After leaving the bubbler the humidity of the air may be reduced by passing it through a dessicant. Care must be taken to insure that the radon becomes wel1 mixed in the space beneath the sand bed, but is not forced up through the bed.

The radon should diffuse up through the sand bed at a constant rate to produce a constant flux of radon from the top of the bed. The radon emanating from the bed should be removed immediately to prevent radon concentrations from increasing above the bed and decreasing the radon flux. Therefore, the air above the bed shouid be circulated through a charcoal trap that is cooled with dry ice. The circulation system should 
be designed so that the speed of the air across the surface of the bed can be varied and can be measured.

The radon flux will depend upon the strength of the ${ }^{226} \mathrm{Ra}$ source and the fraction of the radon that decays before it diffuses through the bed. Different source strengths can be used to produce varying radon fluxes. The fraction of the radon that decays before passing through the bed can be calculated from the one-dimensional diffusion equation. It can be shown that for a $10 \mathrm{~cm}$ thick layer of sand, more than 95\% of the radon should pass through the sand before decaying.

The radon flux through the sand bed can atso be determined by measuring the rate at which radon is collected in the charcoal trap through which the air above the bed is being circulated. The quantity of radon collected in the charcoal trap can be measured either by gamma-ray spectrometry or by heating the trap to desorb the charcoal into a 2 nS scinti1lation cell, and measuring the alpha particle emission rate with a photomultiplier. The charcoal trap should be replaced periodically, and the radon concentration measured to determine whether the measured radon flux is constant. If it is not, the reason for the variation must be discovered and el iminated.

The radon fluxes through the sand bed determined by the above two methods should agree within a few percent. If they do not, then the reason for the discrepancy should be determined before the chamber is used for calibrating the flux measuring devices.

It is important to insure that the radon flux through the sand bed does not vary with location on the bed, so care must be taken to insure that the sand has a constant thickness across the bed. The radon flux should be measured at several times and locations across the bed using charcoal cannisters to determine whether there is a spatial or temporal variation in the flux. If there is, the variation could, of course, be due to inaccuracies in the measurements, but if there is no significant variation, then it can be concluded that the flux is constant. If the measured flux does vary, the reason for the variation must be discovered before the chamber is used for calibrating flux measurirg devices.

It could be that it will not be possible to obtain sufficiently constant fluxes using the chamber described above. In that case, it may be possible to obtain constant fluxes by placing layers of well-blended mixiures of sand and tajlings on the floor of an air-tight chamber. The ratio of sand to tailings can be varied to give radon fluxes covering the range over which the flux measuring devices are expected to be used. The flux, and the temporal variation of the flux, can be measured by circulating the air above the tailings through a charcoal trap that is cooled with dry ice and measuring the rate at which radon is collected in the trap. The temporal and spatial variation in the flux from the bed would be determined by measuring the flux at different times and locations with charcoal cannisters. The objection to this method is that the radon flux could not be re?ated to a standard source of racion. 
Once a facility has been constructed that will produce a constant, known radon flux, it should be used to determine the rates at which the various radon flux measuring devices collect radon as a function of the radon flux. The rate of collection should be given by

$$
C=A F
$$

where $C=$ rate of radon collection (atoms/sec)

$$
A=\text { proportionality constant }\left(\mathrm{cm}^{2}\right)
$$

and $F=$ radon flux (atoms $/ \mathrm{cm}^{2} \cdot \mathrm{sec}$ ).

It is expected that A will approximately equal the area covered by the device. Each device should be used to measure the radon flux over a range of (1) radon flux, (2) air speed across the surface of the bed, (3) temperature and moisture content of the bed and the air, and (4) pressure to determine the magnitude of the variation of $A$. If the variation is too great, then the device cannot be used to measure radon fiuxes accurately. However, even if $A$ does not change with air speed in the calibration facility, it still may change with wind speed in the field because turbulence may cause changes in the radon flux, and the turbulence spectrum of the atmosphere will not be duplicated in the calibration facility. 


\section{References}

Baver, L. D., 1956. Soil Physics, 3rd ed. New York, John Wiley and Sons, pp 209-222.

Bakulin, V. N., 1969. Dependance of Radon Exhalation and Its Concentration in the Soil on Meteorological Conditions (in Russian), Uch. Zap. Kirov. Gos. Pedagog. Inst., 30:70-79.

Bernhardt, D. E., F. B. Jones and R. F. Kaufmann, 1975. Radon Exhalation from Uranium Mill Tailings Piles: Description and Verification of the Measurement Method, U.S. Environmental Protection Agency, Technical Note $0 R P / L V-75-7(A)$.

Bogos lovskaya, I. N., A. G. Grammakov, A. P. Kirkov and P. N. Tverskov, 1932. Report of the work of the Kavgolovo Experimental-Methodical Party in the Year 1931, Izu. Vses. Geol-Razved. Ob"yed 51:1283-1293.

Caplan, P. E., 1972. Calibration of Air Sampling Instruments I -General Considerations and Flow Metering, in Air Sampling Instruments, American Conference of Governmental Industrial Hygienists, pp. H-l to h-8.

Clemerits, W. E., S. Barr, and M. L. Marple, 1978. Uranium Mill Tailings Piles as Sources of Atmospheric Radon-222, Natural Radiation Environment III, PP 1559-1583.

Clements, W. E. and M. H. Wilkening, 1974. Atmospheric Pressure Effects on ${ }^{222} \mathrm{Rn}$ Transport Across the Earth-air Interface, Journal of Geophysical Research, 79:5025-5029.

Colle', R., R. J. Rubin, L. I. Khab, J. M. R. Hutchinson, 1981. Radon Transport Through and Exhalation from Building Materials, NBS Technical Note 1139.

Countess, R. J., 1977. Measurements of ${ }^{222} \mathrm{Rn}$ Flux with Charcoal Canisters, Workshop on Methods for Measuring Radiation in and Around Uranium Mills, Albuquerque, New Mexico, Pp. 139-147.

Duwe, M. F., 1976. The Diurnal Variation in Radon Flux from the Soil due to Atmospheric Pressure Charige and Turbulence. Pho Thesis, University of Wisconsin - Madison.

Ford, Bacon and Davis Utah, Inc., 1981. Engineering Assessment of Inactive Uranium Mill Tailings.

(a) Durango, Colorado, D0E/UMT 103, FBDU-360-06

(b) Shiprock, New Mexico, DOE/UMT 104, F8DU-360-02

(c) Grand Junction, Colorado, D0E/UMT 105, FBDU-360-09

(d) Riverton, Wyoming, DOE/UMT 106, FBDU-360 19 


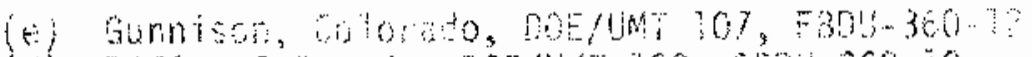

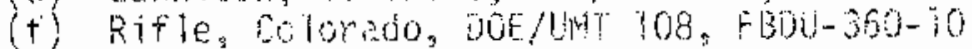

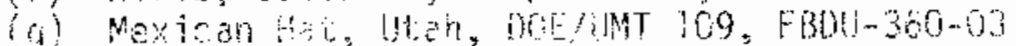

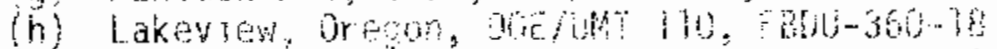

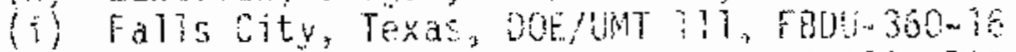

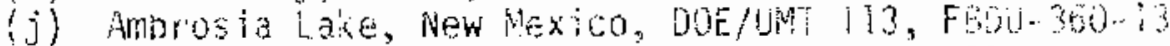

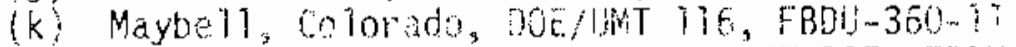

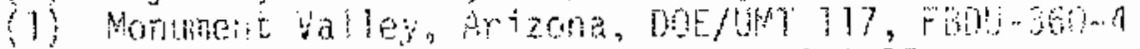

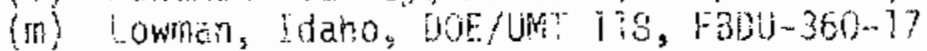

(n) Tuta City, Arizona, o0E/UMT 120, FBou-360-05

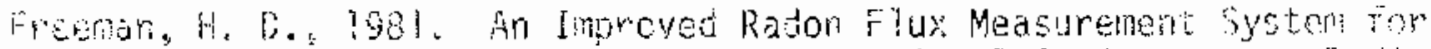

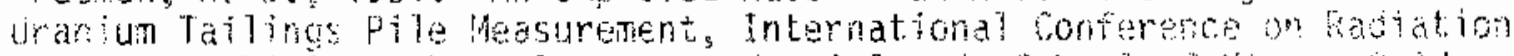

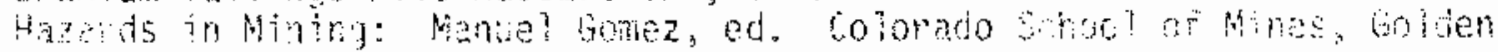
(5).

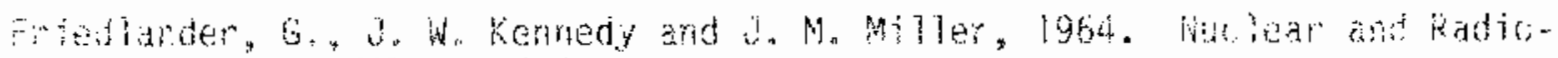
chentsory, John Wijay and Soms.

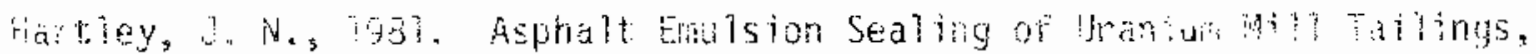

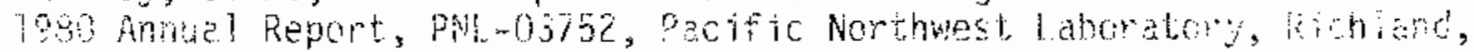
1:.

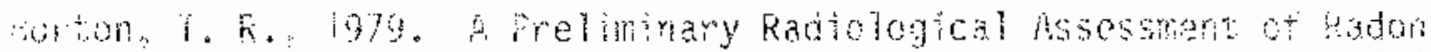

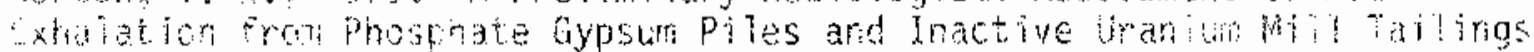

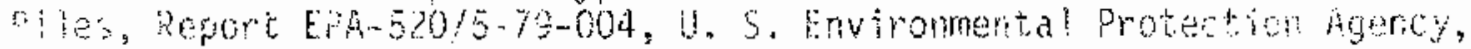

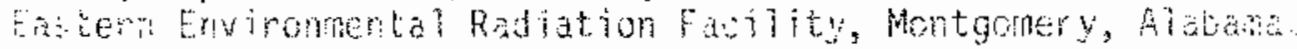

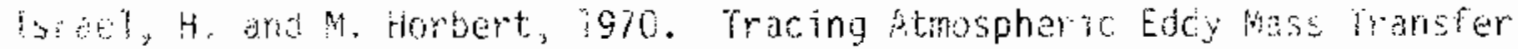

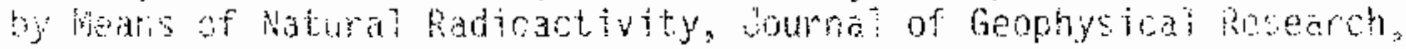
$75: 2891-2297$.

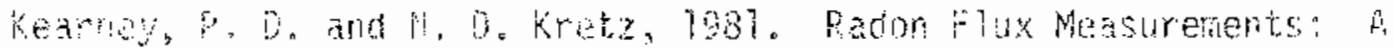

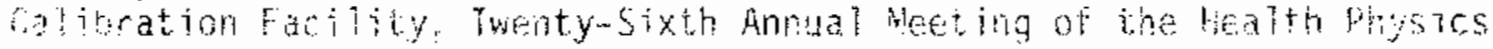

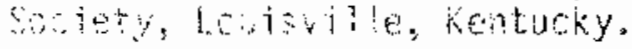

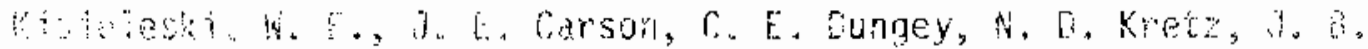

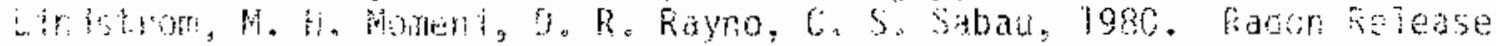

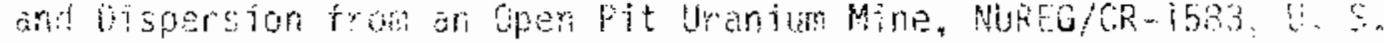

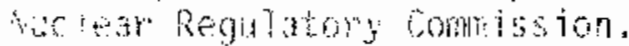

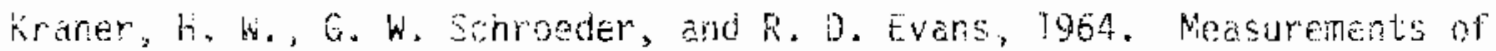
the fffects of Athospheric Variables on Radon-222 Flux and Sol? Gas Concentuations. The Natura? Radiation Environent, pp i91-2is.

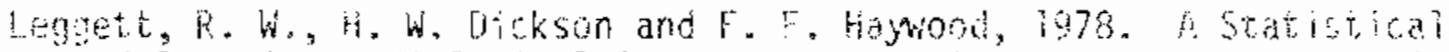
Whadology for Hadiological surveying. TAEa Symposidm on Advianes in Batidion Protection Poritoring, IAE 
Macbeth, P. J., C. M. Jensen, V. C. Rogers and R. F. Overmeyer, 1978. Laboratory Research on Tailings Stabilization Methods and The ir Effectiveness in Radiation Containment, Department of Energy report GJT-21.

Marple, M. L. and Clements, 1977. Measurements of Radon-222 Flux from Inactive Uranium Mill Tailings Piles, ERDA Report LA-6898-PR, Los Alamos Scientific Laboratory, NTIS.

Mayer, D. W. and D. A. Zimmerman, 1981. Radon Diffusion Through Uranium Mill Tailings and Cover Defects, NUREG/CR-2457, PNL-4063.

Megumi, K. and T. Mamuro, 1972. A Method for Measuring Radon and Thoron Exhalation from the Ground, Journal of Geophysical Research, 77:30523056 .

Megumi, K. and T. Mamuro, 1973. Radon and Thoron Exhalation from the Ground, Journal of Geophysical Research, 78:3357-3360.

Momeni, M. H., W. E. Kisieleski, S. Tyler, A. Zielen, Y. C. Yuan, and J. Roberts, 1979. Radiological Impact of Uranium Tailings and Alternatives for their Management, presented at the Health Physics Society Twelfth Midyear Topical Symoosium on Low Level Radioactive Waste Management, February 11, 1979.

Pearson, J. E. and G. E. Jones, 1965. Emanation of Radon-222 from Soils and its Use as a Tracer, Journal of Geophysical Research, 70:5279-5290.

Pearson, J. E. and G. E. Jones, 1966. Soil Concentrations of "Emanating Radium-226" and the Emanation of Radon-222 from Soils and Plants, Tellus 18:655-662.

Rogers, V., R. F. Overmeyer, C. M. Jensen and E. Canon, 1979. Characterization of Uranium Tailings Cover Material for Radon Flux Reduction, prepared by Argonne National Laboratory for Ford, Bacon and Davis Utah, Inc., FBDNI-218-1.

Silker, W. B., and P. G. Heasler, 1979. Diffusion and Exhalation of Radon from Uranium Tailings, NUREG/CR-1138, PNL-3207.

Silker, W. B. and P. G. Heasler, 1979. Diffusion and Exhalation of Radon from Uranium Tajlings, NUREG/CR-1138, PNL-3207.

Styra, B. I., 1968. Selfpurging of the Atmosphere of Radioactive Contamination. Hydrometeorological publication, Leningrad, English translation by M. Lang.

Strong, K. P. and D. M. Levins, 1982. Effect of Moisture Content on Radon Emanation from Uranium Ore and Tailings, Health Physics, 42:27-32.

Tanner, A. B., 1980. Radon Migration in the Ground: A supplementary review, in Natural Radiation Environment III, Vol. 1, pp 1-56. 
Thomas, V. W., K. K. Nielson, and M. L. Mauch, 1982, Radon and Aerosol Release from Open Pit Uranium Mining, NUREG/CR-2407, PNL-4071.

Wilkening, M. H., W. E. Clements, and 0. Stanley, 1972. Radon-222 Flux Measurements in Widely Separated Regions, The Natural Radiation Environment II, Proceedings of the Second International Symposium on the Natural Radiation Environment, Houston, Texas, pp. 717-730.

Wilkening, M., 1977. Measurement of Radon Flux by the Accumulation Method, Workshop on Methods for Measuring Radiation in and Around Uranium Mi11s, Albuquerque, New Mexico, May 23-26, 1977, pp. 131-138. 

NUREG/CR-3166

PNL -4597

DISTR IBUTION

No. of

Copies

OFFSITE

215
U. S. Nuclear Regulatory Commission

Division of Technical Information and Document Control

7920 Norfolk Avenue

Bethesda, MD 20014

C. A. Flory, Program Manager

Low-Level Waste Licensing Branch

Division of waste Management

U. S. Nuclear Regulatory Commission

Moi iston SS-6??

Wastington, ace, 20555

N. I. Abrainiuk

Bendix Field Ergineering Corp.

F.0. Box 1569

Grand Junction, CO 8150 ?

David Balla

U.S. Department of Energy UMTRA

Alouquerque Operations office

Albuquerque, NM 87115

D. Bernhardt.

Office of Radiation Prograns

Environmental Protection Agency

ORP /LVF

P.0. Box 18416

Las Vegas, NV 89114

R. Brich

Qepartment of Health

State of South Dakota

Division of Environmental Health

Foss Butidino

Pisrre, S[ 5750]
No. of

Copies
M. L. Brown

Department of Health

State of Colorado, $125 \mathrm{~N}$. 8th

Grand Junction, Co 81501

$R$. Cooperste in

Environmental and Safety

Engineering Division

U. S. Department of Energy

Washington, D.C. 20545

T. K. Donavan

Project Manager

Eógemont Mill Decontamination

TVA

303 Crystal Building

miatanoge. Th 37t?

J. J. Endres

Special Assistant to the Regional Administrator

Department of Housing and and Urban Development

Executive Tower, 1405 Curt is Street.

Denver, c0 8020?

G. A. Franz

Senior Health Physicist

Department of Health

State of Colorado

125 North 8 th

Grand Junctior, co 81501

J. R. Giedt

Regiona? Radiation Representative

Environmental Protection Agency

1860 Lincoln Street

Denver, Co 80295

W. D. Gisler

Bendix Field Engineering corp.

F. 0. Box 559

Grend Junction, co $8 ! 501$ 


\section{DISTRIBUTION}

No. of

Copies

D. H. Groelsema

U. S. Department of Energy

Washington, D. C. 20545

D. F. Harmon

U. S. Nuclear Regulatory Commission

Washington, D.C. 20555

Fred Haywood

Health and Safety Research Division

Oak Ridge Nationa? Laboratory

P.0. Box $X$

Oak Ridge, TN 37830

A. J. Hazle, Director

Radiation and Hazardous Waste Control Division

Colorado State Department of Health

1405 Curt is Street

Denver, CO 80202

W. Kisieleski

Argonne National Laboratory

9700 South Cass Avenue

Argonne, IL 60439

G. Lane

Council of Energy

Resource Tribes

5660 South Syracuse Circle

Englewood, CO 80111

H. Langner

Department of Health

State of Colorado

125 North 8th

Grand Junction, CO 81501

C. Mc Intyre

State Planning Bureau

Capitol Building

Pierre, SD 5750]
No. of

Copies

\section{RE}


NUREG/CR-3166

PNL.4597

DISTRIBUTION

RE

No. of

Copies

J. Tipton
EG\&G, Incorporated
P. O. Box 1912
Mail Stop P-01
Las Vegas, NV 89101

R. Wallace

Tennessee Valley Authority

River Oaks Building

Muscle Shoals, AL 35660

L. K. Weaver

Department of Health

State of Colorado

125 North 8th

Grand Junction, CO 81501

J. Witherspoon

Oak Ridge National Laboratory

P. 0. $80 x X$

Oak Ridge, TN 37830

R. Wynveen

Occupational Health and

Safety Division

Argonne National Laboratory

9700 South Cass Avenue

Argonne, IL 60439

ONSITE

Pacific Northwest Laboratory

H. D. Freeman

W. A. Glass

J. N. Hartley

P. 0. Jackson

J. M. Nielsen

R. W. Perkins (5)

L. A. Rathbun

V. W. Thomas

N. A. Wogman (5)

J. A. Young (10)

Technical Information (5)

Pubtishing Coordination (2)

Distr. 3 



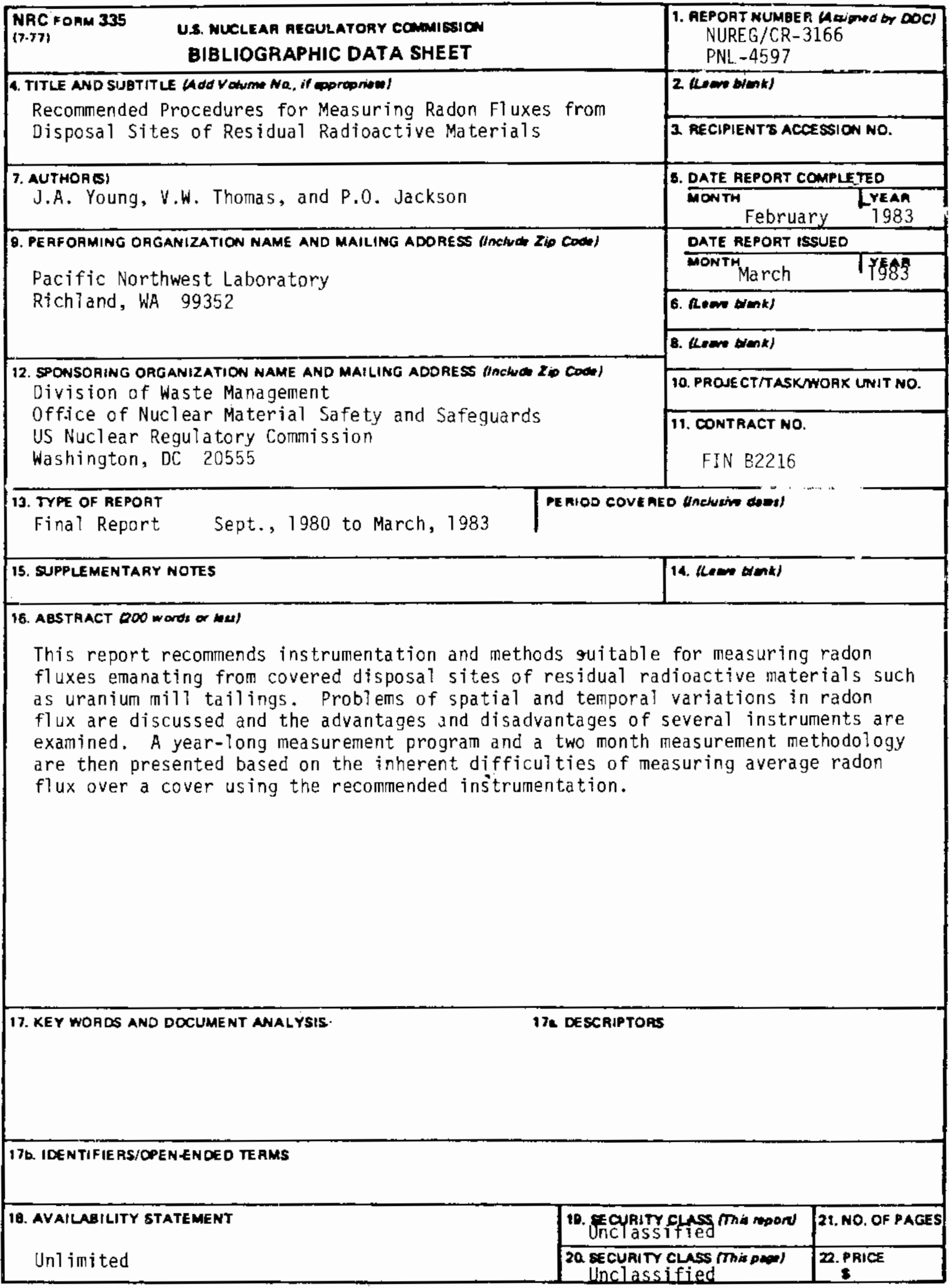


